\title{
Topic Study Group No. 22: Interdisciplinary Mathematics Education
}

\author{
Susie Groves, Julian Williams, Brian Doig, Rita Borromeo Ferri \\ and Nicholas Mousoulides
}

\section{The Programme}

Topic Study Group 22 Interdisciplinary mathematics education included paper presentations and discussion in four main sessions, four oral communication sessions, and one poster presentation session-see below.

The Topic Study Group team also produced the Springer ICME-13 Topical Survey Interdisciplinary Mathematics Education: A State of the Art (Williams et al., 2016) for pre-reading.

Co-chairs: Susie Groves, Julian Williams.

Team members: Brian Doig, Rita Borromeo Ferri, Nicholas Mousoulides.

\footnotetext{
S. Groves $(\bowtie)$

Deakin University, Burwood, Australia

e-mail: susie.groves@deakin.edu.au

J. Williams

The University of Manchester, Manchester, UK

e-mail: julian.williams@manchester.ac.uk

(C) The Author(s) 2017 


\section{Main Sessions}

\begin{tabular}{|c|c|}
\hline Tuesday 12.00-13.30: Chair-Susie Groves & $\begin{array}{l}\text { Wednesday 12.00-13.30: Chair-Rita } \\
\text { Borromeo Ferri }\end{array}$ \\
\hline Introduction to TSG22_-Julian Williams & $\begin{array}{l}\text { Introduction to session 2-Rita Borromeo } \\
\text { Ferri }\end{array}$ \\
\hline $\begin{array}{l}\text { Overview of the TSG } 22 \text { Topical Survey } \\
\text { Interdisciplinary Mathematics Education: A } \\
\text { State of the Art-Susie Groves }\end{array}$ & $\begin{array}{l}\text { A modelling perspective in designing } \\
\text { interdisciplinary professional learning } \\
\text { communities_-Nicholas Mousoulides }\end{array}$ \\
\hline $\begin{array}{l}\text { Theory of disciplinarity and interdisciplinary } \\
\text { activity: Communities, boundaries, voices } \\
\text { and hybridity-Julian Williams and } \\
\text { Wolff-Michael Roth }\end{array}$ & $\begin{array}{l}\text { Mathematics in an interdisciplinary STEM } \\
\text { course }(N L T) \text { in the Netherlands-Nelleke } \\
\text { Susanna den Braber, Jenneke Krüger, Marco } \\
\text { Mazereeuw and Wilmad Kuiper }\end{array}$ \\
\hline $\begin{array}{l}\text { Challenges for mathematics within an } \\
\text { interdisciplinary STEM education- }- \text { Russell } \\
\text { Tytler }\end{array}$ & $\begin{array}{l}\text { Preservice mathematics teachers' } \\
\text { interdisciplinary work for STEM education- } \\
\text { Fatma Aslan-Tutak and Sevil Akaygun }\end{array}$ \\
\hline $\begin{array}{l}\text { Inter-disciplinary mathematics: Old wine in } \\
\text { new bottles? - Brian Doig and Wendy } \\
\text { Jobling }\end{array}$ & $\begin{array}{l}\text { Closing discussion-including possible } \\
\text { research agenda between ICME-13 and } \\
\text { ICME-14 }\end{array}$ \\
\hline \multicolumn{2}{|l|}{$\begin{array}{l}\text { Closing discussion-including possibilities } \\
\text { for a book }\end{array}$} \\
\hline $\begin{array}{l}\text { Friday 12.00-13.30: Chair-Nicholas } \\
\text { Mousoulides }\end{array}$ & $\begin{array}{l}\text { Saturday 12.00-13.30: Chair-Julian } \\
\text { Williams }\end{array}$ \\
\hline $\begin{array}{l}\text { Introduction to session 3-Nicholas } \\
\text { Mousoulides }\end{array}$ & Introduction to session 4-Julian Williams \\
\hline $\begin{array}{l}\text { Scientific inquiry in mathematics and STEM } \\
\text { education -Andrzej Sokolowski }\end{array}$ & $\begin{array}{l}\text { Ratio and proportion in secondary school } \\
\text { science-David Swanson }\end{array}$ \\
\hline $\begin{array}{l}\text { Using real-life context as an aid for } \\
\text { mathematics teaching and learning- } \\
\text { Michael Erotoma Omuvwie }\end{array}$ & $\begin{array}{l}\text { Interdisciplinary communication between } \\
\text { music and mathematics: An experience with } \\
\text { stochastic music-María Alicia Venegas } \\
\text { Thayer }\end{array}$ \\
\hline $\begin{array}{l}\text { Quantitative reasoning: Rasch measurement } \\
\text { to support } Q R \text { assessment - } \text { Robert Lee } \\
\text { Mayes, Kent Rittschof, Jennifer Forrester and } \\
\text { Jennifer Christus }\end{array}$ & $\begin{array}{l}\text { Inspired by Leonardo da Vinci-STEM } \\
\text { learning for primary and secondary school } \\
\text { with the Cross-Link Approach-Rita } \\
\text { Borromeo Ferri, Andreas Meister, Detlef } \\
\text { Kuhl and Astrid Hülsmann }\end{array}$ \\
\hline $\begin{array}{l}\text { Closing discussion - including possible } \\
\text { Discussion Group or Working Group at } \\
\text { ICME-14 }\end{array}$ & $\begin{array}{l}\text { Closing discussion - including decision on } \\
\text { possible Springer book }\end{array}$ \\
\hline
\end{tabular}




\section{Oral Communications}

\begin{tabular}{|c|c|}
\hline Tuesday 15.00-16.00: Chair-Brian Doig & $\begin{array}{l}\text { Tuesday 16.30-18.00: Chair-Rita Borromeo } \\
\text { Ferri }\end{array}$ \\
\hline $\begin{array}{l}\text { Mathematics and sciences teachers } \\
\text { collaboratively design interdisciplinary } \\
\text { lesson plans: Benefits, limitations, and } \\
\text { concerns-Atara Shriki and Ilana Lavy }\end{array}$ & $\begin{array}{l}\text { Investigating interdisciplinary approaches } \\
\text { and commitments through pre-service } \\
\text { teachers' use of mathematics and poetry- } \\
\text { Nenad Radakovic, Limin Jao and Susan } \\
\text { Jagger }\end{array}$ \\
\hline $\begin{array}{l}\text { Teaching and applying research methods in a } \\
\text { cross-cultural project for students of } \\
\text { mathematics education-Mutfried Hartmann, } \\
\text { Thomas Borys, Arno Bayer and Tetsushi } \\
\text { Kawasaki }\end{array}$ & $\begin{array}{l}\text { Mathematics and medicine: A study of } \\
\text { thinking and variational language - } \\
\text { Gloria Angélica Moreno Durazo and Ricardo } \\
\text { Cantoral }\end{array}$ \\
\hline $\begin{array}{l}\text { Doing inter-disciplinary work in mathematics } \\
\text { education: Potentialities and challenges- } \\
\text { Sikunder Ali Baber }\end{array}$ & $\begin{array}{l}\text { Teachers' readiness to mathematics and } \\
\text { science integration-Betul Yeniterzi, } \\
\text { Cigdem Haser, and Mine Isiksal-Bostan }\end{array}$ \\
\hline $\begin{array}{l}\text { Interdiciplinary activities in context }- \text { Maite } \\
\text { Gorriz, and Santi Vilches }\end{array}$ & $\begin{array}{l}\text { Incorporating mathematics, creative writing, } \\
\text { literature and arts in the classroom- } \\
\text { Frederick Lim Uy }\end{array}$ \\
\hline Friday 15.00-16.00: Chair-Susie Groves & $\begin{array}{l}\text { Friday 16.30-18.00: Chair-Nicholas } \\
\text { Mousoulides }\end{array}$ \\
\hline $\begin{array}{l}\text { A cloud based performance support system } \\
\text { for teaching STEM with hands-on modeling } \\
\text { - Roberto Araya }\end{array}$ & $\begin{array}{l}\text { Integrating mathematics, engineering and } \\
\text { technology through mathematics modeling } \\
\text { and video representations-Carlos Alfonso } \\
\text { LopezLeiva, Marios Pattichis and Sylvia } \\
\text { Celedon-Pattichis }\end{array}$ \\
\hline $\begin{array}{l}\text { Korean mathematics textbook analysis: } \\
\text { Focusing on competence, on contexts and } \\
\text { ways of integration-Jong-Eun Moon, } \\
\text { Mi-Yeong Park, Jeong Soo-Yong and } \\
\text { Mi-Kyung Ju }\end{array}$ & $\begin{array}{l}\text { An experimental textbook system for financial } \\
\text { mathematics for the integration of finance } \\
\text { and mathematics-OhNam Kwon, JungSook } \\
\text { Park, JeeHyun Park, Jaehee Park and } \\
\text { Changsuk Lee }\end{array}$ \\
\hline $\begin{array}{l}\text { Mathematics of money dynamics-Francesco } \\
\text { Scerbo, Elena Scordo and Laura Vero }\end{array}$ & $\begin{array}{l}\text { Co-disciplinary mathematics and physics } \\
\text { research and study courses (RSC) in the } \\
\text { secondary school and the university-Maria } \\
\text { Rita Otero, Vivianna Carolina Llanos, Maria } \\
\text { Paz Gazzola and Marcelo Arlego }\end{array}$ \\
\hline $\begin{array}{l}\text { Transcending the mathematics classroom- } \\
\text { Signe E. Kastberg, Rachel Long, Kathleen } \\
\text { Lynch-Davis and Beatriz S. D'Ambrosio }\end{array}$ & $\begin{array}{l}\text { Investigating students' difficulties with } \\
\text { differential equations in physics-Diarmaid } \\
\text { Aidan Hyland, } \\
\text { Paul van Kampen and Brien Nolan }\end{array}$ \\
\hline
\end{tabular}




\section{Posters-Tuesday 18.00-20.00}

Assessment of mathematical competencies of biology teacher trainees - Ivana Boboňová and Soňa Čeretková

Relationahips of cognitive domains: Focus on reasoning and applying in mathematics and science-Amanda Meiners, Jihyun Hwang and Kyong Mi Choi

QUBES: Quantitative Undergraduate

Biology Education and Synthesis - Carrie

Diaz Eaton, Sam Donovan, Stith T. Gower and Kristin Jenkins

Usage of mathematics competency in a new context in science: Experience of Latvia - Ilze France, Lìga Čakāne, Uldis Dzērve, Dace Namsone and Jānis Vilciņš

Enacting planets-Emmanuel Rollinde

Students' aspirations for STEM careersKathryn Holmes, Adam Lloyd, Jennifer Geometry from a global perspective - Craig Russell

Geometry in Slovak blueprint-Soňa

Čeretková and Edita Smiešková

Gore, Max Smith, Leanne Fray and Claire Wallington

Fostering of interdisciplinary competences through basic education in computer science in mathematics in primary school-Peter Ludes

An interdisciplinary activity on angiogenesis - Catherine Langman, Judi Zawojewski and Patricia McNicholas

Preparing STEM teachers as researchers: A research experiences for undergraduates project - Jennifer Wilhelm and Molly H. Fisher

Relationahips of cognitive domains: Focus on reasoning and applying in mathematics and science-Amanda Meiners, Jihyun Hwang and Kyong Mi Choi

Interdisciplinary mathematics education is a relatively new field of research, which has become increasingly prominent because of the political agenda around STEM. However, there are also increasing mathematical demands outside STEMfor example, the need to effectively critique the vast amounts of statistical information evident in all aspects of society-as well as increasing interest in how mathematics inter-relates with other disciplines and contexts.

The level of interest in interdisciplinary mathematics education was evident in the number of presentations and participants at the main sessions and oral communications, and the vibrant discussions that took place. Presentations were complemented by a range of posters that allowed a wide group of attendees to discuss ideas of interdisciplinarity during the poster viewing time.

Disciplinarity is a social phenomenon, marked by increasing specialization and differentiation of practices, professional disciplines - such as nursing, teaching, physiotherapy — often defined by practical competence. It is often difficult for those schooled in one field to relate effectively with others from relatively independent and contradictory fields, with boundaries between disciplines notoriously difficult to cross, which might explain why interdisciplinarity is often praised rhetorically but so difficult to practice.

Interdisciplinarity occurs across a continuum ranging from mono-disciplinarity to meta-disciplinarity. Mono-disciplinarity involves a single discipline only, while 
multi-disciplinarity involves two or more disciplines, but in both these cases the disciplines themselves may remain intact. Inter-disciplinarity, on the other hand, involves some sort of hybridising of "multi" disciplines-e.g. chemistry and biology becoming biochemistry. Trans-disciplinarity acquires its transcendence due to disciplines being subsumed in joint problem solving enterprises that may perhaps result in a new form of mathematics. While multi-disciplinarity and trans-disciplinarity offering hybridity of disciplines, the disciplines themselves are not displaced, but instead provide the value interdisciplinarity requires. Meta-disciplinarity transpires in an awareness of relationships and differences between disciplines - e.g. the contrasting nature of "using evidence" in history and science may be contrasted and thereby clarified (see Williams et al., 2016).

As can be seen from the programme details, presenters covered a wide range of topics under the umbrella of interdisciplinarity. Presenters provided views of interdisciplinarity from several academic disciplines, including mathematics, physics, medicine and music, as well as across much of the spectrum of interdisciplinarity discussed above. In addition, presenters represented a wide cross-section of countries, which added to the notion that interdisciplinarity is indeed of global interest and importance. Of particular note were presentations and posters outside the expected scientific disciplines, for example, music and poetry. Discussion following each presentation allowed a range of perspectives to be aired. Attendees brought to the discussion the perspectives of many different educational cultures, their affordances and their constraints.

The review of the literature carried out as part of the pre-ICME Topical Survey showed that interdisciplinary mathematics education is relatively under-developed as a research subfield. There is some evidence of beneficial outcomes of interdisciplinary work in integrated curricula that often involves projects, with these benefits typically emphasising motivational, affective and problem-solving learning outcomes. The papers and presentations reinforced these conclusions.

Progress in interdisciplinary mathematics education appears to be hampered by a lack of clarity and consensus about the concept of disciplinarity and how to adequately describe "interdisciplinary" interventions and programs, together with a lack of consistency about relevant learning outcomes and how they can be identified and measured, and a lack of research on which future work can build.

Interdisciplinary mathematics education offers the opportunity to encourage possibly disaffected students to reconsider mathematics. It offers mathematics to the wider world in the form of added value - e.g. in problem solving — and, conversely, it offers the added value of the wider world to mathematics. Therefore interdisciplinary mathematics education should be a major topic for mathematics education and can be expected to become much more prominent in educational research and practice.

Discussion among the large group of session attendees, almost all of whom attended all main sessions, was fruitful. Plans were made to set up a website for 
continued contact among members of the Topic Study Group between ICME congresses, with a decision to be made closer to ICME-14 as to whether to attempt to continue the Topic Study Group or try to reconvene as a Discussion Group.

All participants were invited to submit abstracts for a proposed Springer monograph, with approximately 25 proposals for chapters currently under review.

\section{Reference}

Williams, J. M., Roth, W.-M., Swanson, D., Doig, B., Groves, S., Omuvwie, M., .., Mousoulides, N. (2016). Interdisciplinary mathematics education: A state of the art. Berlin: Springer. doi:10. 1007/978-3-319-42267-1

Open Access Except where otherwise noted, this chapter is licensed under a Creative Commons Attribution 4.0 International License. To view a copy of this license, visit http://creativecommons. org/licenses/by/4.0/.

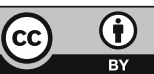

